\title{
KARAKTERISTIK PASIEN KONFIRMASI COVID-19 DI RSUD LAMADDUKKELLENG KABUPATEN WAJO (TINJAUAN PASIEN PERIODE MARET-SEPTEMBER 2020)
}

\section{Characteristics of Covid-19 Confirmation Patients in Lamaddukkelleng Hospital, Wajo District (Patient Review for March-September 2020 Period)}

\author{
Asti Pratiwi Duhri, Rubin Jabbar, Nuraini Yunus \\ RSUD Lamaddukkelleng Kabupaten Wajo \\ astiduhri@gmail.com
}

\begin{abstract}
The increasing number of Covid-19 cases could increase the number of patients in the hospital. There were 236 Covid-19 patients at Lamaddukkelleng Hospital until September 30, 2020, and 163 of them tested positive for Covid-19. This study aims to determine the characteristics of Covid-19 confirmation patients at Lamaddukkelleng Hospital in March-September 2020. A descriptive review was carried out on patient data for confirmation of Covid19. The method of data collection is done by using passive-active surveillance methods. Data processed and analyzed using the SPSS program by presenting the frequency and proportion data for each variable. Most of the patients who confirmed Covid-19 at Lamaddukkelleng Hospital were women (57.7\%),41-50 years old (23.3\%), and domiciled in Tempe District. Most of the patients were outpatients (90.8\%) and had no symptoms (88.9\%). Most of the patients did not have a history of contact with Covid-19 confirmed patients (55.8\%) and had never traveled to a local or overseas transmission area within the last 14 days before the examination (95.7\%). A total of 160 patients (98\%) confirmed positive at RSUD Lamaddukkelleng, Wajo Regency had no comorbid and there are two confirmed positive patients who died (CFR $=1.2 \%$ ).
\end{abstract}

Keywords: Covid-19, Characteristics, RSUD Lamaddukkelleng

\section{ABSTRAK}

Jumlah kasus Covid-19 yang semakin meningkat dapat mengakibatkan peningkatan jumlah pasien di rumah sakit. Pasien Covid-19 di RSUD Lamaddukkelleng hingga 30 September 2020 sebanyak 236 orang dan 163 diantaranya dinyatakan positif Covid-19. Studi ini bertujuan untuk mengetahui karakteristik pasien konfirmasi Covid-19 di RSUD Lamaddukkelleng pada bulan Maret-September 2020. Review deskriptif dilakukan terhadap data pasien konfirmasi Covid-19. Cara pengumpulan data dilakukan dengan metode surveilans aktif pasif. Data diolah dan dianalisis menggunakan program SPSS dengan menyajikan data frekuensi dan proporsi untuk setiap variabel. Sebagian besar pasien konfirmasi Covid19 di RSUD Lamaddukkelleng adalah perempuan (57,7\%), berumur 41-50 tahun (23,3\%), dan berdomisili di Kecamatan Tempe. Sebagian besar pasien adalah pasien rawat jalan $(90,8 \%)$ dan tidak memiliki gejala $(88,9 \%)$. Sebagian besar pasien tidak memiliki riwayat kontak dengan pasien konfirmasi Covid-19 $(55,8 \%)$ serta tidak pernah melakukan perjalan ke daerah transmisi lokal atau ke luar negeri dalam waktu 14 hari terakhir sebelum pemeriksaan (95,7\%). Sebanyak 160 pasien (98\%) konfirmasi positif di RSUD Lamaddukkelleng Kabupaten Wajo tidak memiliki komorbid dan terdapat dua pasien konfirmasi positif yang meninggal (CFR=1,2\%).

Kata kunci : Covid-19, Karakteristik, RSUD Lamaddukkelleng

\section{PENDAHULUAN}

Coronavirus Disease 2019 (Covid-19) merupakan penyakit baru yang belum pernah terjadi sebelumnya. Covid-19 ini disebabkan oleh Severe Acute Respiratory Syndrome Coronavirus 2 (SARS-CoV-2) dan memiliki tingkat penularan yang sangat cepat (Kemenkes, 2020). Rata-rata masa inkubasi Covid-19 adalah 5-6 hari sedangkan masa inkubasi terpanjang adalah 14 hari. Covid-19 pada kasus yang berat dapat menyebabkan sindrom pernapasan akut, pneumonia, gagal ginjal, dan bahkan kematian (Kemenkes, 2020).

Covid-19 pertama kali dilaporkan sebagai kasus pneumonia yang tidak diketahui etiologinya di Kota Wuhan, Provinsi Hubei, Cina. Hingga 28 September 2020, Covid-19 telah menginfeksi 32,7 juta jiwa dengan angka kematian 3,03\% (WHO, 2020).

Asia Tenggara menyumbang $21 \%$ dari total kasus global, dengan $11 \%$ kematian (WHO, 2020). Kasus pertama di Indonesia ditemukan pada tanggal 2 Maret 2020 dan terus meningkat serta menyebar dengan cepat di seluruh wilayah Indonesia. Sampai dengan tanggal 27 September 2020 Kementerian Kesehatan melaporkan 275.213 kasus konfirmasi Covid-19 dengan 10.386 kasus meninggal (CFR 3,8\%) (Satgas Covid, 2020).

Sulawesi selatan menjadi provinsi dengan kasus tertinggi di luar pulau jawa. Sampai dengan tanggal 27 September 2020 Kementerian Kesehatan melaporkan 15.295 kasus konfirmasi COVID-19 di Sulawesi Selatan dangan angka kematian (CFR) sebesar 2,7\% (Satgas Covid, 2020). 
Kabupaten Wajo sebagai salah satu kabupaten di Sulawesi Selatan juga memiliki kontribusi dalam peningkatan kasus COVID19 di Sulawesi Selatan. Satuan Tugas Penangan Covid-19 Wajo melaporkan jumlah kasus konfirmasi positif di Kabupaten Wajo sampai dengan tanggal 30 September 2020 adalah 180 kasus dengan 3 kasus meninggal ( $\mathrm{CFR}=1,7 \%$ ).

Jumlah kasus Covid-19 yang semakin meningkat dapat mengakibatkan peningkatan jumlah pasien di rumah sakit. RSUD Lamaddukkelleng Kabupaten Wajo sebagai salah satu rumah sakit rujukan tingkat kabupaten juga melakukan pelayanan Covid-19 berupa perawatan suspek, serta pemeriksaan laboratorium radiologi dan pemeriksaan penunjang lainnya dalam rangka penegakan diagnosis Covid-19. Adapun untuk pasien yang sudah terkonfirmasi Covid-19 tidak dirawat di RSUD Lamaddukkelleng, akan tetapi dirujuk di RS rujukan Covid-19 atau di hotel yang telah disediakan Pemerintah Provinsi Sulawesi Selatan dalam program Wisata Covid-19 bagi pasien tanpa gejala.

Pasien Covid-19 di RSUD Lamaddukkelleng hingga 30 September 2020 sebanyak 236 orang dan 163 diantaranya dinyatakan positif Covid- 19 .

Studi ini bertujuan untuk mengetahui karakteristik pasien konfirmasi Covid-19 di RSUD Lamaddukkelleng pada bulan MaretSeptember 2020.

\section{METODE}

Review deskriptif dilakukan terhadap data pasien yang berasal dari rekam medis dan form penyelidikan epidemiologi. Penelitian dilakukan di RSUD Lamaduukkelleng Kabupaten Wajo pada periode Maret-September 2020.

Pasien yang dimasukkan dalam analisis adalah pasien dengan konfirmasi positif berdasarkan hasil swab RT-PCR. Karakteristik dasar yang kami amati adalah jenis kelamin, umur, tempat tinggal, jenis perawatan, riwayat perjalanan, riwayat kontak, gejala, komorbid, dan kematian akibat Covid-19.

Cara pengumpulan data dilakukan dengan metode surveilans aktif pasif. Surveilans aktif dilakukan dengan pengambilan data langsung ke gedung isolasi covid serta pengisian form PE melalui wawancara dengan pasien atau keluarga pasien, adapun surveilans pasif berasal dari laporan petugas surveilans puskesmas yang akan merujuk pasien untuk melakukan swab test.

Data diolah dan dianalisis menggunakan program SPSS dengan menyajikan data frekuensi dan proporsi untuk setiap variabel.

\section{HASIL}

Kasus konfirmasi positif yang melakukan pemeriksaan selama periode Maret-September 2020 sebanyak 163 pasien. Pasien perempuan lebih banyak dibandingkan pasien laki-laki (94 pasien; $57,7 \%$ ). Umur pasien sangat bervariasi mulai dari yang termuda berumur 2 tahun sampai yang tertua berumur 77 tahun. Pengelompokan umur dibuat sesuai dengan kategori dalam pelaporan RS Online, sebagian besar pasien berada pada rentang 41-50 tahun yaitu 38 pasien $(23,3 \%)$. Berdasarkan tempat tinggal, pasien konfirmasi positif paling banyak tinggal di Kecamatan Tempe sebanyak 77 orang $(47,2 \%)$

Sebagian besar pasien adalah pasien rawat jalan $(148 ; 90,8 \%)$ dan tidak memiliki gejala $(145 ; 88,9 \%)$. Pasien yang bergejala sebagian besar merasakan gejala khas infeksi saluran napas seperti demam (14 pasien), batuk (12 pasien), dan sesak (6 pasien). Gejala lain yang dirasakan adalah mual/muntah (5 pasien), pilek (3 pasien), lemah (2 pasien), serta sakit tenggorokan, sakit kepala, dan nyeri abdomen masingmasing 1 pasien.

Sebanyak 72 pasien (44,2\%) mengatakan pernah kontak dengan pasien konfirmasi Covid-19 dalam waktu 14 hari terakhir sebelum melakukan pemeriksaan. Sedangkan 91 pasien lainnya tidak memiliki riwayat kontak dengan pasien konfirmasi Covid-19 (55,8\%). Sebagian besar pasien menyangkal pernah melakukan perjalanan ke daerah transmisi lokal atau ke luar negeri dalam waktu 14 hari terakhir sebelum pemeriksaan $(95,7 \%)$. Hanya tujuh pasien yang mengaku pernah melakukan perjalanan ke daerah transmisi lokal atau ke luar negeri dalam waktu 14 hari terakhir sebelum pemeriksaan (4,3\%).

Sebanyak 160 pasien (98\%) konfirmasi positif di RSUD Lamaddukkelleng Kabupaten Wajo tidak memiliki komorbid. Hal ini didukung oleh data sebelumnya bahwa sebagian besar kasus konfirmasi positif adalah kasus asimptomatik (tanpa gejala). Adapun pasien konfirmasi positif yang disertai komorbid sebesar 2\% (3 
pasien) yang semuanya menderita Diabetes melitus dan dua diantaranya juga menderita Hipertensi. Terdapat dua pasien konfirmasi positif yang meninggal ( $C F R=1,2 \%)$, keduanya berumur diatas 50 tahun dan memiliki komorbid.

\section{PEMBAHASAN}

Kasus konfirmasi positif Covid-19 di RSUD Lamaddukkelleng pada bulan MaretSeptember 2020 didominasi oleh perempuan yaitu sebanyak 94 orang. Berdasarkan data tersebut dapat diketahui proporsi pasien perempuan sebesar $57,7 \%$, dan rasio perempuan terhadap laki-laki adalah 1,36.

Penelitian tentang hubungan jenis kelamin dengan risiko terinfeksi Covid-19 masih beragam. Sebuah penelitian di Denmark menemukan proporsi perempuan tertular virus lebih besar daripada laki-laki (54\%). Sejalan dengan hasil survei pada 9 dari 18 negara yang sudah memisahkan kasusnya berdasarkan jenis kelamin, menunjukkan bahwa kasus Covid-19 sebagian besar adalah perempuan. Adapun di Iran, kasus Covid-19 justru lebih banyak pada laki-laki (57\%). Hal ini sejalan dengan survey 6 dari 18 negara yang memiliki kasus Covid19 lebih banyak pada laki-laki dibandingkan perempuan. Lain halnya dengan Jerman, Swedia, dan Norwegia memiliki kasus Covid-19 yang sebanding antara laki-laki dan perempuan (Sulaiman dkk, 2020).

Sebagian besar pasien konfirmasi positif Covid-19 di RSUD Lamaddukkelleng pada bulan Maret-September 2020 sebagian besar berada pada kelompok umur 41-50 tahun dengan total 38 orang $(23,3 \%)$, sedangkan yang paling sedikit adalah kelompok umur 1-10 dan 61-70 tahun yaitu masing-masing sebanyak 9 orang $(5,5 \%)$.

Sebuah studi menunjukkan pentingnya struktur umur dalam mengetahui kelompok masyarakat yang berisiko tinggi dan menjelaskan besarnya dampak dan penyebaran COVID-19 (Dowd dkk dalam Wijaya, 2020). Semakin bertambah usia sesorang maka semakin tinggi pula risiko dampak yang dimiliki saat terinfeksi Covid19. Hal ini berkaitan erat dengan tingkat imunitas yang semakin menurun seiring bertambahnya usia. Sebuah penelitian menunjukkan bahwa persentase pasien pada usia 10 tahun kebawah lebih kecil dibanding pasien usia dewasa atau lansia (diatas usia 70 tahun) yang mencapai $70 \%$. Hal ini menunjukkan adanya kecenderungan bahwa semakin bertambahnya usia seseorang berkorelasi positif dengan risiko tertular COVID-19 (Wijaya,2020).

Hasil analisis menunjukkan bahwa pasien konfirmasi positif terbanyak berada pada kecamatan Tempe sebanyak 77 orang $(47,2 \%)$, disusul oleh kecamatan Tanasitolo sebanyak 25 orang (15,3\%). Kota Sengkang yang merupakan ibu kota kabupaten Wajo berada di kecamatan Tempe, sehingga kecamatan Tempe merupakan pusat kegiatan perkantoran, perdagangan, wisata masyarakat di kabupaten Wajo yang dapat mengakibatkan kepadatan penduduk sehingga meningkatkan potensi penularan.

Sejalan dengan penelitian di Manado yang menunjukkan bahwa pada kecamatan dengan kepadatan tinggi maka kejadian Covid-19 berada pada kategori sedang dan tinggi (Nelwan, 2020). Sebuah penelitian di Amerika Serikat dan China juga menyatakan bahwa kepadatan penduduk dapat mempengaruhi waktu terjadinya transmisi secara positif karena jarak antar wilayah yang berdekatan dengan jumlah penduduk yang juga padat (Carozzi et al., 2020; Li et al., 2020).

Berdasarkan status perawatan, sebagian besar pasien terkonfirmasi positif di RSUD Lamaddukkelleng merupakan pasien rawat jalan yaitu sebanyak 148 orang $(90,8 \%)$. Hal ini menunjukkan bahwa sebagian besar pasien konfirmasi positif di RSUD Lamaddukkelleng merupakan orang tanpa gejala atau memiliki gejala ringan yang tidak membutuhkan perawatan di rumah sakit. Hal ini sesuai dengan pedoman pemberantasan covid di Indonesia yang menyatakan bahwa pasien yang dirawat di rumah sakit adalah pasien dengan gejala sedang hingga berat (Kemenkes, 2020)

Sebagian besar pasien konfirmasi positif tidak memiliki gejala (145; 88,9\%). Pasien yang bergejala sebagian besar merasakan gejala khas infeksi saluran napas seperti demam (14 pasien), batuk (12 pasien), dan sesak ( 6 pasien). Gejala lain yang dirasakan adalah mual/muntah (5 pasien), pilek (3 pasien), lemah (2 pasien), serta sakit tenggorokan, sakit kepala, dan nyeri abdomen masing-masing 1 pasien.

Banyaknya kasus orang tanpa gejala perlu menjadi perhatian karena hal ini menunjukkan kemungkinan terjadinya fenomena gunung es, yaitu banyaknya 
kasus yang tidak terjaring karena tidak adanya gejala yang terdeteksi. Risiko penularan juga dapat semakin meningkat diantara orang-orang tanpa gejala karena menganggap diri mereka tidak sakit sehingga tingkat kewaspadaan pun berkurang. Sejalan dengan penelitian yang dilakukan oleh Emery et al. (2020) yang menyatakan Infeksi SARS-CoV-2 asimtomatik dapat berkontribusi secara substansial untuk transmisi.

Sebanyak 72 pasien (44,2\%) mengatakan pernah kontak dengan pasien konfirmasi Covid-19 dalam waktu 14 hari terakhir sebelum melakukan pemeriksaan. Sedangkan 91 pasien lainnya tidak memiliki riwayat kontak dengan pasien konfirmasi Covid-19 (55,8\%). Studi ini sejalan dengan hasil penelitian di Semarang yang menemukan bahwa sebagian besar pasien yang dirawat di RS Umum Pusat Dr. Kariadi tidak memiliki riwayat perjalanan dan tidak memiliki kontak dengan pasien konfirmasi positif (Minuljo dkk, 2020).

Sebagian besar pasien menyangkal pernah melakukan perjalan ke daerah transmisi lokal atau ke luar negeri dalam waktu 14 hari terakhir sebelum pemeriksaan $(95,7 \%)$. Hanya tujuh pasien yang mengaku pernah melakukan perjalanan ke daerah transmisi lokal atau ke luar negeri dalam waktu 14 hari terakhir sebelum pemeriksaan (4,3\%). Hal ini menunjukkan bahwa sebagian besar sumber penularan merupakan transmisi lokal. Sejalan dengan pernyataan WHO bahwa penyebaran kasus Covid-19 di Indonesia bersifat community transmission (WHO, 2020).

Sebanyak 160 pasien (98\%) konfirmasi positif di RSUD Lamaddukkelleng Kabupaten Wajo tidak memiliki komorbid. Hal ini didukung oleh data sebelumnya bahwa sebagian besar kasus konfirmasi positif adalah kasus asimptomatik (tanpa gejala). Adapun pasien konfirmasi positif yang disertai komorbid sebesar 2\% (3 pasien) yang semuanya menderita Diabetes melitus dan dua diantaranya juga menderita Hipertensi. Penelitian Adityo Susilo dkk tahun 2020 juga menyatakan bahwa penyakit komorbid hipertensi dan DM adalah faktor risiko infeksi SARS-COV2.

Menurut Minuljo dkk (2020), kombinasi antara penyakit Diabetes mellitus dengan usia lanjut memperkuat risiko turunnya kemampuan respon imun dalam menghadapi infeksi Covid-19.
Terdapat dua pasien konfirmasi positif yang meninggal (CFR $=1,2 \%$ ), keduanya berumur diatas 50 tahun dan memiliki komorbid. Beberapa hasil penelitian (Bonanad et al., 2020; Niu et al., 2020; Liu et al., 2020; Li et al., 2020; Leung, 2020; Shahid et al., 2020; Zhou et al., 2020) mendukung bahwa risiko penularan dan kematian berkorelasi dengan struktur umur penduduk. Ada hubungan yang erat antara faktor umur dengan tingkat penularan dan risiko kematian. Risiko penularan dan kematian pada pasien lanjut usia lebih tinggi, terlebih lagi pada pasien yang memiliki komorbid seperti diabetes, hipertensi, jantung, dan gangguan pernafasan. Chinese Centre for Disease Control (2020) juga menyatakan bahwa case fatality rate akibat Covid-19 pada pasien DM jauh lebih tinggi dibandingkan pasien non DM (7,3\& vs $2,3 \%$ ) (Hill et al., 2020).

\section{KESIMPULAN}

Sebagian besar pasien konfirmasi Covid-19 di RSUD Lamaddukkelleng adalah perempuan $(57,7 \%)$, berumur $41-50$ tahun $(23,3 \%)$, dan berdomisili di Kecamatan Tempe. Sebagian besar pasien adalah pasien rawat jalan $(90,8 \%)$ dan tidak memiliki gejala $(88,9 \%)$. Sebagian besar pasien tidak memiliki riwayat kontak dengan pasien konfirmasi Covid-19 (55,8\%) serta tidak pernah melakukan perjalan ke daerah transmisi lokal atau ke luar negeri dalam waktu 14 hari terakhir sebelum pemeriksaan $(95,7 \%)$. Sebanyak 160 pasien (98\%) konfirmasi positif di RSUD Lamaddukkelleng Kabupaten Wajo tidak memiliki komorbid dan terdapat dua pasien konfirmasi positif yang meninggal (CFR=1,2\%).

\section{SARAN}

Saran untuk masyarakat agar meningkatkan kesadaran untuk mematuhi protokol kesehatan serta meningkatkan daya tahan tubuh agar dapat menurunkan risiko penularan Covid-19. Untuk pemerintah dan instansi terkait agar memperketat pelaksanaan Peraturan Bupati Wajo Nomor 87 tahun 2020 tentang penerapan disiplin dan penegakan hukum protokol kesehatan dengan pemberlakuan denda bagi pelanggar protokol kesehatan. Penelitian selanjutnya diharapkan melakukan uji korelasi terhadap hubungan karakteristik dan faktor risiko Covid-19 
terhadap angka kejadian konfirmasi Covid19.

\section{UCAPAN TERIMA KASIH}

Terima kasih kepada Direktur RSUD Lamaddukkelleng, Kepala bidang Rekam Medik Pengawasan dan Pengendalian, Kepala seksi rekam medik, Kepala seksi pengawasan dan pengendalian penyakit, serta rekan-rekan kerja, tim surveilans, dan tim covid atas dukungan dan kerjasamanya dalam proses pengumpulan data dan penyelesaian laporan ini.

\section{DAFTAR PUSTAKA}

Bonanad C, Sergio Garcia-Blas, Francisco Tarazona-Santabalbina, Juan Sanchis, Vincente BertomeuGonzalez, Lorenzo Facila, Albert Ariza, Julio Nunez, Alberto Codero. 2020. The Effect of Age on Mortality in Patients with Covid-19: A Metanalysis with 611.583 Subjects. Journal of the American Medical Directors Association, doi: 10.1016/j. jamda.2020.05.045.

Caroozi P, Sandro and Sefi Roth. 2020. Urban Density and Covid 19. https://ideas.repec.org/p/iza/ izadps/dp13440.html (Diakses 8 Oktober 2020).

Dowd J B, Liliana Andrianoa, David M. Brazela, Valentina Rotondia, Per Blocka, Xuejie Dinga, Yan Liua, and Melinda C. Millsa. 2020. Demographic science aids in understanding the spread and fatality rates of COVID-19. Vol. 117 , No. 18, Proceedings of the National Academy of Sciences (PNAS), doi: 10.1073/pnas. 2004911117.

Emery JC, Russell TW, Liu Y, et al. The contribution of asymptomatic SARSCoV-2 infections to transmission on the Diamond Princess cruise ship. elife. Aug 24, 2020. https://elifesciences.org/articles/ 58699 (Diakses 8 Oktober 2020).

Hill M A, Christos Mantzoros, James R. Sowers. 2020. Commentary: COVID-19 in Patients with Diabetes. https://www.ncbi.nlm. nih.gov/pmc/articles/PMC7102643/ (Diakses 8 Oktober 2020).
Kemenkes RI. 2020. Keputusan Menteri Kesehatan Republik Indonesia Nomor HK.01.07/MENKES/ 413/2020 tentang Pedoman Pencegahan dan Pengendalian Coronavirus Disease 2019 (Covid19). $\quad$ https://covid19.go.id/p/ regulasi/keputusan-menteri-

kesehatan-republik-indonesianomor-hk0107menkes4132020 (Diakses 5 Oktober 2020).

Leung, Char. 2020. Risk factors for predicting mortality in elderly patients with COVID-19: A review of clinical data in China. Mechanisms of Ageing and Development 188, doi: 10.1016/j.mad.2020.111255.

Li, Qun et al. 2020. Early Transmission Dynamics in Wuhan, China of Novel Coronavirus- Infected Pneumonia. The New England Journal of Medicine. https://www. neim.org/doi/full/10.1056/ nejmoa2001316 (Diakses 8 Oktober 2020).

Minuljo T T, Yohana Prima Ceria Anindita, Heri Nugroho Hario Seno, Tjokorda Gde Dalem Pemayun, Muchlis Achsan Udji Sofro. 2020. Karakteristik dan Keluaran Pasien COVID-19 dengan DM di RS Umum Pusat Dr. Kariadi (Tinjauan pasien periode Maret-Juli 2020). http:// medicahospitalia.rskariadi.co.id/ medicahospitalia/index.php/mh/artic le/view/473 (Diakses 8 Oktober 2020).

Nelwan, Jeini Ester. 2020. Kejadian Corona Virus Disease 2019 Berdasarkan Kepadatan Penduduk dan Ketinggian Tempat Per Wilayah Kecamatan.

https://ejournal.unsrat.ac.id/ index.php/iiphcm/article/view/ 29176 (Diakses 8 Oktober 2020).

Niu S, Sijia Tian, Jing Lou, Xuqin Kang, Luxi Zhang, Huixin Lian, Jinjun Zhang. 2020. Clinical Characteristics of Older Patients Infected with COVID19: A Descriptive Study. Archives of Gerontology and Geriatrics, 89, doi: 10.1016/j.archger.2020. 104058.

Satuan Tugas Penanganan Covid Indonesia. 2020. Analisis Data Covid-19 Indonesia Update per 27 September 2020. 
https://covid19.go.id/p/berita/analisi s-data-covid-19-indonesia-update$\begin{array}{ll}\text { 27-september-2020 } & \text { (Diakses } 8\end{array}$ Oktober 2020).

Satuan Tugas Penanganan Covid Wajo. 2020. Data Pantauan Covid-19 di Kabupaten Wajo. http://covid19. wajokab.go.id//Diakses 8 Oktober 2020).

Shahid Z, Ricci Kalayanamitra, Brendan McClafferty, Douglas Kepko, Devyani Ramgobin, Ravi Patel, Chander Shekher Aggarwal, Ramarao Vunnam, Nitasa Sahu, Dhirisha Bhatt, Kirk Jones,

Sulaiman, Reza. 2020. Lelaki atau Perempuan, Siapa yang Lebih Rentan Terinfeksi Virus Corona. https://www.suara.com/health/ (Diakses 5 Oktober 2020).

Susilo, Adityo dkk. 2020. Coronavirus Disease 2019: Tinjauan Literatur Terkini. https://ocw.ui.ac.id/ (Diakses 5 Oktober 2020). Reshma Golamari, dan Rohit Jain. 2020. COVID-19 and Older Adults: What We Know. Journal of The American Geriatrics Society 68, doi: 10.1111/jgs. 16472.

Wijaya, Angga. 2020. Pandemi COVID-19: Struktur Umur dan Risiko Kematian". https://kependudukan. lipi.go.id/ (Diakses 5 Oktober 2020).
World Health Organization. 2020. Coronavirus disease (COVID-19) Weekly Epidemiological Update and Weekly Operational Update. https://www.who.int/docs/defaultsource/coronaviruse/situationreports/20200928-weekly-epiupdate.pdf?sfvrsn $=9 \mathrm{e} 3546656$ (Diakses 8 Oktober 2020).

World Health Organization. 2020. WHO Coronavirus Disease (COVID-19) Dashboard. covid19.who.int (Diakses 8 Oktober 2020).

Zhou F, Ting Yu, Ronghui Du, Guohui Fan, Ying Liu, Zhibo Liu, Jie Xiang, Yeming Wang, Bin Song, Xiaoying sGu, Lulu Guan, Yuan Wei, Hui Li, Xudong $\mathrm{Wu}$, Jiuyang $\mathrm{Xu}$, Shengjin Tu, Yi Zhang, Hua Chen, Bin Cao. 2020. Clinical course and risk factors for mortality of adult inpatients with COVID-19 in Wuhan, China: a retrospective cohort study. Lancet 395, doi: 10.1016/ S0140-6736(20)30566-3. 
Tabel 1

Karakteristik Pasien Konfirmasi Covid-19 di RSUD Lamaddukkelleng Kabupaten Wajo

\begin{tabular}{|c|c|c|}
\hline Variabel & & n (\%) \\
\hline Jenis Kelamin & $\begin{array}{l}\text { Laki-laki } \\
\text { Perempuan }\end{array}$ & $\begin{array}{l}69(42,3) \\
94(57,7)\end{array}$ \\
\hline Umur (tahun) & $\begin{array}{l}1-10 \\
11-20 \\
21-30 \\
31-40 \\
41-50 \\
51-60 \\
61-70\end{array}$ & $\begin{array}{c}9(5,5) \\
10(6,1) \\
36(22,1) \\
37(22,7) \\
38(23,3) \\
24(14,7) \\
9(5,5)\end{array}$ \\
\hline Tempat tinggal (kecamatan) & $\begin{array}{l}\text { Belawa } \\
\text { Bola } \\
\text { Gilireng } \\
\text { Keera } \\
\text { Majauleng } \\
\text { Maniangpajo } \\
\text { Pammana } \\
\text { Penrang } \\
\text { Pitumpanua } \\
\text { Sabbangparu } \\
\text { Takkalalla } \\
\text { Tanasitolo } \\
\text { Tempe }\end{array}$ & $\begin{array}{c}9(5,5) \\
2(1,2) \\
4(2,5) \\
2(1,2) \\
6(3,7) \\
7(4,3) \\
16(9,8) \\
4(2,5) \\
2(1,2) \\
6(3,7) \\
3(1,8) \\
25(15,3) \\
77(47,2)\end{array}$ \\
\hline Jenis Perawatan & $\begin{array}{l}\text { Rawat inap } \\
\text { Rawat Jalan }\end{array}$ & $\begin{array}{c}15(9,2) \\
148(90,8)\end{array}$ \\
\hline Gejala & $\begin{array}{l}\text { Ada } \\
\text { Tidak ada }\end{array}$ & $\begin{array}{c}18(11,1) \\
145(88,9)\end{array}$ \\
\hline Kontak erat & $\begin{array}{l}\text { Ya } \\
\text { Tidak }\end{array}$ & $\begin{array}{l}72(44,2) \\
91(55,8)\end{array}$ \\
\hline Riwayat perjalanan & $\begin{array}{l}\text { Ada } \\
\text { Tidak ada }\end{array}$ & $\begin{array}{c}7(4,3) \\
156(95,7)\end{array}$ \\
\hline Komorbid & $\begin{array}{l}\text { Ada } \\
\text { Tidak ada }\end{array}$ & $\begin{array}{c}160(98,0) \\
3(2,0)\end{array}$ \\
\hline Status keluar & $\begin{array}{l}\text { Hidup } \\
\text { Meninggal }\end{array}$ & $\begin{array}{c}161(98,8) \\
2(1,2)\end{array}$ \\
\hline
\end{tabular}




\section{Tabel 2}

Distribusi Pasien Konfirmasi Covid-19 Berdasarkan Gejala dan Komorbid di RSUD Lamaddukkelleng Kabupaten Wajo

\begin{tabular}{llc}
\hline & Variabel & $\mathrm{n}$ \\
\hline Gejala & Demam & 14 \\
& Batuk & 12 \\
& Sesak & 6 \\
& Pilek & 3 \\
& Nyeri tenggorokan & 1 \\
& Sakit kepala & 1 \\
& Mual/muntah & 5 \\
& Nyeri abdomen & 2 \\
Komorbid & & \\
& & 2 \\
& Hipertensi & 3 \\
\hline
\end{tabular}

